University of California, Hastings College of the Law

UC Hastings Scholarship Repository

Faculty Scholarship

2020

Corporate Behavior and the Tax Cuts and Jobs Act

Manoj Viswanathan

Nicholas H. Cohen

Follow this and additional works at: https://repository.uchastings.edu/faculty_scholarship 


\title{
Corporate Behavior AND the TAX CUTS AND JOBS ACT
}

\author{
by Nicholas H. Cohen and Manoj Viswanathan
}

The Tax Cuts and Jobs Act of 2017 (the "TCJA") fundamentally altered United States tax law. Among other things, it broadly decreased income tax rates paid by individuals and corporations, eliminated miscellaneous itemized deductions, limited the state and local tax deduction, increased the standard deduction, reduced the alternative minimum tax for individuals and eliminated it entirely for corporations, and allowed a deduction for certain pass-through business income.

TCJA proponents, generally Republicans, claimed that its $\$ 1.5$ trillion of tax cuts would result in significant economic benefits. In particular, TCJA supporters believed that the tax benefits afforded U.S. corporations,[1] most notably the reduction in rate from 35 percent to 21 percent, would incentivize corporations to use their additional after-tax cash in ways generally beneficial to the U.S. economy. Predicted indicia of these salutary effects included increases in the rate growth of gross domestic product, increased national capital stock, and significant increases to workers' wages. TCJA opponents instead expected its benefits to inure almost entirely to a small group of investors and corporate managers. Many critics (generally Democrats and deficit hawks) considered the TCJA a distributionally unsound way to allocate such a significant tax cut.

Corporations have operated for nearly two years under this new corporate tax regime. Their most recent annual corporate filings provide information from the first full calendar year in which the TCJA's provisions are in full effect. These reports contain information on effective tax rate, capital expenditures, $\mathrm{CEO}$ compensation, and other important metrics of corporate activity and productivity. From this data we can analyze the preliminary effects the TCJA has had on these corporations and assess the extent to which claims made by the TCJA's proponents on corporate behavior have been borne out. While other studies have considered the TCJA's effect on specific corporate attributes, this Essay is the first to assess the TCJA's effect on a range of corporate behaviors by using recently filed, publicly available data on a granular, corporation-by-corporation basis.

Specifically, our study assesses the extent to which changes in effective tax rates for the top cohort of companies in the Standard \& Poor's 500 index (S\&P 500) relate to a variety of corporate behaviors purportedly affected by the TCJA.[2] Our results indicate that the TCJA's reduction in effective tax rate had zero relationship to number of employees; dividends paid; capital expenditures; cash flow from operations; market value; capital expenditure ratio; research and development ratio; earnings before interest and taxes (EBIT); earnings before interest, taxes, depreciation and amortization (EBITDA); and total executive compensation. Our 
study indicates that the TCJA's reduction in effective tax rate has a small relationship to CEO compensation and total value of shares repurchased. Although the effects (or non-effects) of the TCJA may not be known for years, our study indicates that the anticipated economic benefits of the TCJA due to its changes to effective corporate tax rate have yet to be observed. Indeed, the reduced effective corporate tax rates might promote certain less desirable corporate behaviors, such as increased CEO compensation and increased numbers of stock shares repurchased.

This Essay proceeds in four parts. Part I describes how the TCJA modified the corporate income tax code and details the purported economic benefits of the TCJA, focusing on claims that were made just prior to the TCJA's passage. Part II describes our study's methodology, presents our statistical results, and discusses limitations to our analysis. Part III discusses the implications of our study on the economics of corporate tax rates. The Appendix includes a full description of our methodology.

$* * *$

\section{TCJA Changes to Corporate Taxation and Predicted Economic Effects}

The TCJA made many important changes to U.S. corporate income tax law. Most fundamentally, the TCJA reduced the statutory rate on all corporate income to a flat 21 percent from a previous top marginal rate of 35 percent. Beyond reducing the statutory rate, the TCJA also affected several other provisions relevant for corporations, including those concerning earnings stripping, expensing and depreciating, net operating losses, and the taxation of foreign subsidiaries. [3] In addition, it created a global intangible low-taxed income (GILTI) regime[4] and the foreign-derived intangible income (FDII) deduction. [5]

These TCJA provisions influence corporations in various ways. The specific operations of a particular business affect the tax benefits (or penalties) to which the business might be subjected. A corporation with little foreign operations, for instance, will have little use for the FDII deduction. In the aggregate, however, the TCJA is unequivocally corporation-friendly: it generally reduces the taxes paid by corporations despite an increase in corporate profits. This reduction in corporate tax liability was marketed by TCJA supporters as a necessary stimulus for the U.S. economy.

TCJA proponents expected that corporations paying lower taxes would have greater access to cash flows. These cash flows could be deployed to invest in capital expenditures, such as research, development, and upgraded plants and equipment. These investments would result in a boom of productivity, increasing the marginal value created by each employee. This, in turn, would cause increased hiring of new 
employees and increased compensation for existing employees. Proponents also expected that corporations would take advantage of decreased repatriation taxes to "onshore" cash previously held in foreign subsidiaries; this would create beneficial effects similar to the decreased corporate income tax rate.

Proponents also expected that investor behavior would change in ways that were beneficial to the general economy. The assumption inherent in this view is that investors have a largely constant expectation of after-tax returns on deployed capital for a given level of risk asset. Decreasing the corporate tax rate would, therefore, increase the supply of capital, as more investment opportunities would offer the desired after-tax return on investment. Similar to the actions of corporations, this would result in increased capital expenditures, eventually increasing employment levels and average incomes via the same path.

Trump administration officials and other prominent Republicans frequently reiterated these purported economic benefits of the TCJA. Senate Majority Leader Mitch McConnell predicted that the economic growth catalyzed by the tax cuts would result in the bill's revenue neutrality. Former House Speaker Paul Ryan stated that the corporate tax cuts would lead directly to the creation of new jobs, and not to corporations redistributing the newfound cash to shareholders. Kevin Hassett, Chairman of the Council of Economic Advisers, claimed that the reduced corporate income rate and expanded expensing provisions would promote higher wages to workers and increased capital expenditures. And last but not least, President Donald Trump promised that the TCJA would result in more American jobs, bigger paychecks for workers, repatriation of trillions of dollars of corporate cash, a rocket-fueled economy, and a one-page tax filing for the vast majority of taxpayers.

$* * *$

\section{Effect of Tax Rate Reductions on Corporate Behaviors}

Our analysis considers the natural experiment engendered by the passage of the TCJA. It compares the change in effective tax rate and its relationship on measurable corporate behavior as reported in the first set of post-TCJA 10-K filings. (The Securities and Exchange Commission requires all corporations with publicly offered equity, as well as corporations meeting other criteria, to file $10-\mathrm{K}$ forms each year.) The complexity of corporate tax laws ensures a dramatic divergence between the statutory corporate tax rate of 21 percent and effective corporate tax rates, where effective rate is defined as total worldwide taxes divided by total worldwide earnings. Some of these divergences are related to identifiable corporate features (such as industry group), but others are unique to a corporation's specific tax situation. This tax rate divergence ensures that corporations have experienced vastly different consequences from the TCJA. Companies already paying little tax, 
for example, would see almost no rate reduction from the TCJA. In contrast, corporations paying the maximum pre-TCJA statutory rate of 35 percent are nearly guaranteed to see large reductions in effective tax rate. Proponents of the TCJA would expect these more affected corporations to take the actions described previously, thereby creating positive externalities for the U.S. economy. Corporations with little reduction in effective tax rate would not be expected to change their actions. If these actions are a function of their respective corporations' change in tax rate, this would indicate the TCJA is affecting corporate behaviors.

We considered the one hundred companies with the largest weightings in the S\&P 500 , excluding financial companies, as well as certain firms that had not published 2018 annual results at the time of the study. We also excluded outlier companies with an unusually large relative tax benefit, with a tax rate greater than 75 percent, or with an absolute value of change in deferred income tax of at least $\$ 15$ billion between 2017 and 2018. This left ninety-one companies within our study.

To represent the period before the passage of the TCJA, we considered both the change in effective tax rate from 2017 alone, as well as the change in effective tax rate using an average from years 2015,2016 , and 2017 as the base year. These relative changes in effective tax rate were then compared to several dependent variables to determine the effect, if any, on corporate behavior. The twelve dependent variables against which the change in effective tax rate were tested are (1) number of employees; (2) dividends paid; (3) capital expenditures; (4) cash flow from operations; (5) market value; (6) capital expenditure ratio; (7) research and development ratio; (8) EBIT; (9) EBITDA; (10) total executive compensation; (11) CEO compensation; and (12) total value of shares repurchased. We used three control variables in the study: corporate market capitalization, number of employees, and tax rate.

As expected, the effective income tax rate decreased significantly within our group of corporations. Using the single year base of 2017 , the mean and median decrease in effective tax rate was 5.8 percent and 4.5 percent, respectively, with 71 of 91 companies reporting a decrease in effective tax rate. Using the multi-year base of years 2015-2017, the mean and median decrease was even larger, 9.8 percent and 8.0 percent, respectively, with 72 of 91 companies experiencing a relative decrease in tax rate. The summary statistics for the corporate behaviors studied are contained in Tables 1 and 2 of the Appendix.

Our analysis revealed that few corporate behaviors were affected by change in effective tax rate to a statistically significant degree. This includes two specific corporate behaviors, number of employees and capital expenditure ratio, which TCJA proponents indicated would change due to decreased corporate tax rates. The only dependent variables showing any statistical significance are CEO 
compensation, using the single base year of 2017 , and total value of shares repurchased, using the 2015-2017 average. This implies that the decrease in effective corporate tax rate bears some relationship - though likely not a causal relationship-to both increased CEO compensation and total value of shares repurchased.

While our study has shown no evidence of widespread benefits of any kind resulting changes in corporate behaviors due to changes in effective corporate tax rates, there are limitations to our analysis. We focused on only the largest, publicly-listed U.S. corporate entities. It is possible that smaller companies or private companies might behave differently than the corporations in our sample set. In addition, as this study was intended as a survey, we did not analyze sub-samples, such as industry type; as such, there may be ways to further parse the data that could return different results. Also, our study considers only one year after the passage of the TCJA, which may be too brief of a period for corporations to take action due to decreased tax rates. Finally, different corporations could make accounting decisions that render comparisons of the type included here imperfect; it is possible that different methods of managing data would produce different conclusions. $* * *$

\section{Rationales for Corporate Behaviors (and Non-Behaviors)}

Our analysis indicates that post-TCJA corporate behavior accords little with what TCJA proponents predicted. The reasons for this lack of observed corporate behavior due to changes in effective tax rate are far from clear, but potential explanations can be posited.

Even before its passage, opponents of the legislation expressed strong reasons to believe that corporations would do little with their tax savings other than returning it to investors in the form of stock buybacks or overcompensating management. Corporations have many sources of cash other than after-tax earnings. Total checkable deposits and currency on non-financial corporate balance sheets as of the first quarter of 2019 total approximately $\$ 926$ billion. In addition, as of February 2020, highly rated "AA" companies could borrow funds at an effective interest rate of approximately 2.1 percent; even corporations that borrow in the higher-yielding "junk bond market" (rating "BB") had an approximate average interest rate of only 3.7 percent. If corporations already have vast access to cash reserves that they were not investing, the relatively smaller, additional cash flow from tax savings is unlikely to be significantly invested in company operations.

There was historical precedent that the repatriation holiday would produce little benefit. A similar measure was attempted through the American Jobs Creation Act (AJCA) of 2004; but few corporations took advantage of the provision at the time. 
The ACJA also created a perverse, long-term disincentive for corporations to repatriate future earnings due to expectations of future one-time tax cuts, which was one reason why corporate assets in extraterritorial subsidiaries had greatly increased in the interim. The similarity between the repatriation provisions of the AJCA and the TCJA could be expected to produce similar results.

Other theories could explain why TCJA provisions affecting investor tax liabilities would not positively affect the economy via increased worker wages or increased capital expenditures. Macroeconomics dictates that, in an economy closed to foreign investment, savings must equal investment. By virtue of this "savings identity," for total invested capital to increase in an economy, the savings rate must increase. The likely source for this increase is decreased consumption. However, this decreased consumption diminishes economic output, offsetting the benefits of increased investment. In the medium term, efficiency gains resulting from investment could outweigh the short-term drag caused by this decreased consumption. However, in the first eighteen months after its passage, the increased capital expenditures included in rosy projections of the TCJA's effects have not materialized.

The savings identity argument against the TCJA could, potentially, be mitigated by the fact that the United States is not a closed economy. Capital can travel almost freely into the United States from many other countries. It is possible that the newly decreased corporate tax rate would result in greatly increased foreign investment in the United States, creating productivity gains without domestic consumption loss. However, if the equilibrium level of after-tax return on investment is roughly fixed (an assumption of TCJA proponents, as discussed above), then cross-border investment opportunities are correspondingly limited. Our analysis reveals no evidence of an increase in net foreign capital flows since the passage of the TCJA.

$* * *$

\section{Conclusion}

Despite a decline in effective tax rate that is, on average, approximately five percent from the year preceding the TCJA, and ten percent from years 2015-2017, there are few indicia of the corporate-investment-led economic boom predicted by Trump administration officials. While it is difficult to definitively know why corporations have not significantly reinvested their tax savings in their employees, property, plants, or equipment, we have identified economic theories that predict such a lack of activity. Should further studies find similar results, they will support theories predicting that the incidence of corporate taxation falls mainly upon investors (as opposed to employees or customers), and that investor behavior is largely inelastic with respect to moderate changes in tax rates. 
The TCJA cut taxes by $\$ 1.5$ trillion and in the process conferred significant tax benefits on U.S. corporations. Unlike the predictions of the TCJA's proponents, economic growth has shown no sign of increasing nearly to the extent necessary for the tax cut to pay for itself. In addition to increases in discretionary spending passed shortly after the TCJA, the United States now faces the largest federal budget deficit it has ever experienced during a period of peace and economic growth. While the long-term impacts of fiscal profligacy are as uncertain as the tax policy effects on economic growth, we should expect that such a sizable reduction in federal tax revenue comes with some economic benefits to offset the burden of increased debt. Based on our study, we have not found any such benefits in the postTCJA behavior of U.S. corporations.

$* * *$

Nicholas Cohen is the Founder and Principal of LobbySeven LLC, where he regularly publishes on fiscal policy through a quantitative lens. Manoj Viswanathan is an Associate Professor of Law at the University of California, Hastings College of the Law. Thanks to Amrita Sethi for outstanding research assistance.

$* * *$

\section{Footnotes}

[1] Although the TCJA did affect the taxation of S-corporations, this Essay focuses on C-corporations. Thus, all references to "corporations," unless otherwise specified, are to C-corporations.

[2] Our measure of "effective tax rate" is not the GAAP effective tax rate reported in corporate filings. See Appendix (describing methodology for calculating effective tax rate).

[3] The TCJA permits a U.S. corporation that owns at least 10 percent of certain foreign corporations to deduct an amount equal to the foreign-source portion of any dividend received from the foreign corporation, in essence creating a modified territorial system of taxation.

[4] The GILTI regime imposes a minimum tax rate on foreign income, inducing U.S. corporations to keep income-generating intellectual property in the United States.

[5] FDII is income greater than some fixed return on a corporation's depreciable, tangible return, and is subject to a lower tax rate. 